International

Medical Society

http://imedicalsociety.org

\title{
Self Care
}

\section{Assisted in People with Tuberculosis Treatment \\ OBACIMALI}

\begin{abstract}
Erika Simone Galvão Pinto1, Ana Luisa Brandão de Carvalho Lira², Maria Isabel da Conceição Dias Fernandes ${ }^{3}$, Aline Ale Beraldo ${ }^{4}$, Reinaldo Antonio da Silva Sobrinho5, Maria de Lourdes Costa da Silva1, Paula Fernanda Brandão Batista dos santos', Rayla Patrícia da Silva Andrade ${ }^{6}$, Tereza Cristina Scatena Villa ${ }^{7}$
\end{abstract}

\section{Abstract}

Introduction: In supported self-care, health professionals encourage individuals to take care of themselves from the adoption of healthy habits. In the case of patients with TB, self-care is important because it can contribute to the reduction of treatment abandonment.

Objective: To analyze self-care in treating people with tuberculosis assisted in health facilities of primary care and compare the scores of self-care supported by the type of service and the professional health function.

Method: A Cross-sectional study in a city in northeastern Brazil, with 100 professionals (nurses, nursing technicians, medical and health community agents) working in the health units of primary care. Data collection was conducted from November 2013 to January 2014, using a structured questionnaire proposed by MacCooll Institute for Health Care Innovation, specifically the area of supported self-care. Descriptive and inferential statistics were used for the analysis. The Research Ethics Committee approved the study, by the protocol: 456,332.

Results: The four items of supported self-care were identified (support, records, reception and behavior change interventions), most of the health facilities, a reasonable capacity of attention to people with TB. When it was assessed among professionals and the types of units, it was also rated with a reasonable capacity, statistical difference.

Conclusion: It was found that the self-care supported practiced by primary health care professionals is effective in helping the individuals
1 Ph.D., Professor of the Department of Nursing, Federal University of Rio Grande do Norte. *

2 Ph.D., Professor of the Department of Nursing and the Graduate Program in Nursing, Federal University of Rio Grande do Norte. *

3 Ph.D. student of Graduate Nursing, Federal University of Rio Grande do Norte. *

4 Ph.D. in Nursing, University of São Paulo.

5 Ph.D. in Nursing, Professor of the Department of Nursing and Graduate Program in Nursing, State University of West Paraná. Foz do Iguaçu, Paraná, Brazil.

6 Specialization Student, Teaching, Research and Extension Board (CENPEX). *

7 Ph.D. in Nursing, Professor of the Department of Nursing and the Graduate Program in Nursing, Ribeirão Preto Nursing School. Ribeirão Preto, São Paulo, Brazil.

*: Natal, Rio Grande do Norte, Brazil

\section{Contact information:}

\section{Contact information}

Address: $4 \mathrm{~A}$

Tel: (513) 270

Fax: (513) 226

” steXXen@sjofXXom 
with tuberculosis, having in view the homogeneity found in capacity classified as reasonable between the various units of the municipality, the types of unit and the categories of professionals.

\section{Keywords}

Primary Health Care;

Tuberculosis; Self Care; Health

Personnel.

\section{Introduction}

People with chronic health conditions experience physical and psychological changes, continuous medication, dependence on family members and limitations in practical activities that hinder the interaction with society and promote wellbeing. Thus, there are barriers related both to the individual (behavioral, psychological, social and economic), such as those related to health services (hosting, link, medical care guarantee, medicines, and examinations).

In this scenario, tuberculosis (TB) is a chronic condition considered in its epidemiological context as a priority by the Federal Government and has the national pacts, the implementations of actions networks and services established from the needs of the population [1].

TB is a contagious infectious disease that mainly affects people who live with someone with the disease who have immunosuppression or comorbidities, who are institutionalized, and health professionals who perform high-risk activities and people in precarious conditions and/or living in agglomerations [2]. In this sense, it is considered a direct disease linked to poverty and particularly affects developing countries [3].

Worldwide, between 1990-2010, the TB mortality rate has decreased by almost $80 \%$, from a total of 216,000 to 55,000 deaths and the prevalence rate decreased half [3]. In Brazil, in 2014, the region with the highest rate of new cases was the South, which had a total of $84.54 \%$ of cases; the Midwest and the North were second, with a total of approximately $60 \%$, and the Northeast and Southeast regions, with $58 \%$ of cases [4]. Regarding mortality, the number is around 49,000 to 57,000 people, the prevalence among 51000-180000 and the incidence is 86000-95000 [5].

Given these figures, it is up to the primary health care to capture, meet and link patients with suspected tuberculosis. Thus, it has as skills conducting active surveillance of respiratory symptoms, facilitating the examinations for early diagnosis, establishing the basic treatment, controlling defaulters in treatment, investigating possible contacts with suspected TB, identifying the occurrence of adverse effects to drugs recommended and offering support to carriers of the disease, to facilitate any obstacles that may hinder the treatment or living with the disease [6].

Given these skills, it is necessary the support provided by the health team of primary care to patients with $T B$, and it is essential to decrease the dropout rates of treatment of the disease in Brazil. In a study of the main reasons for abandoning treatment, there are: alcohol, drugs, reactions resulting from the use of drugs, socioeconomic problems, religion, the difficulties of access to medicines, ties established between the professional and the patient, and perception healing before the treatment ends [7].

In this sense, providing the supported self-care can help the TB carrier to live with the limitations imposed by the disease and treatment, decreasing the chances of abandonment of therapy. Self-care is to preserve life activities, health, development, and well-being performed by the person. Thus, through self-care actions health promotion issues are implemented [8].

In the supported self-care, health professionals, in different sites of action, encourage individuals to take care of themselves from the adoption of 
healthy life habits. Therefore, it takes some interventional techniques that favor this change, as the assessment of knowledge and ideas on the subject person, counseling, pact on short and long term goals, care and change monitoring process [9].

In the case of patients with TB, self-care is important since it can contribute to the reduction of abandonment to treat tuberculosis. With this intervention, the level of acceptance and completion of treatment tends to increase. Given the importance of this action, the question is: is the supported selfcare a frequent activity in the actions of health professionals? Is there a relationship between the supported self-care and professional category or type of unit that performs this intervention? Therefore, the objective of this study is to analyze supported self-care in the treatment of people with TB assisted in primary care health units and compared the scores of self-care supported by the type of service and the professional health function.

\section{Methods}

This is a cross-sectional study with professionals in the health units of Primary Care in a city in northeastern Brazil.

To obtain the quantity of human resources by professional category (physician, nurse, nursing assistant and/or nursing technician and community health worker) who work in the health units of primary care and has accompanied TB cases has conducted a survey in the Municipal Health Department of the Municipality (SMS).

Thus, the study population was 384 professionals of health facilities of primary care, and the sample calculation considered the following parameters used in the formula for finite population: sampling error 0.05 , the confidence interval of $95 \%$ and population ratio of $50 \%$, obtained with a sample of 100 professionals, who were randomly selected.

To participate in the survey, four health professionals were chosen in the selected health units, being a professional for each category: doctor, nur- se, nursing technician and Community Health Agent (CHA). To chose the units, a random drawing of the 27 health units where these professionals work was held. In the case of refusal, another professional who has already accompanied a TB carrier to complete the 100 health professionals replaced the professional randomly.

The following inclusion criteria were used: professionals from primary care units that have accompanied TB cases, excluding professionals on sick leave or vacation during the period of data collection.

For data collection carried out from November 2013 to January 2014, a structured questionnaire proposed by MacCooll Institute for Health Care Innovation instrument adapted and validated in Brazil was applied for the evaluation of professional and local institutional capacity to develop a model of care for chronic conditions [10]. The instrument is divided into seven dimensions for the interaction of the primary health care professionals, their organizational structure and care of patients with tuberculosis. However, this study investigated the size was about self-care supported for individuals with TB. This dimension has the following components: records related to the support of the Health Unit of professionals for with tuberculosis care of their own health; support (health education and bond with the professionals); host of the concerns of people with TB and their families, and behavior change interventions (quit smoking, drinking, drug use).

Responses were divided into four levels $(D, C, B$, A), $D$ being the worst level with scores from 0 to 2; level $C$ of 3 to 5; Level B 6 to 8 (where the two intermediate levels); and level $A$, the most favorable score with 9 to 11. Each level had the following interpretation: Level D - limited capacity for attention to people with TB; Level C - Basic ability to care for patients with TB, Level B - reasonable capacity for attention to patients with TB and Level A - great capacity for attention to people with TB. They were calculated from the arithmetic mean of the sum of the scores of each dimension divided by the number of components. 
From the instrument variables, the data were organized, categorized and coded. Data analysis was performed using the SPSS version 22.0 for Windows Statistic package. Descriptive statistics were used to analyze the mean and standard deviation of each item of the instrument. For the inferential analysis, ANOVA was used to compare the means between the types of health services (UBS, USF, Mixed Unit), as well as the function performed by the Health Unit by the professional (CHA, Nursing Technician, Nurse, and Doctor).

It is noteworthy that the Basic Health Unit (BHU) receives spontaneous demand of the population or programmatic and no ascription of customers; in the Family Health Unit (USF) there are delimitations of clientele and has a team of doctors, nurses, nursing technicians and CHA; and finally, the Mixed Unit, is characterized by being a unit to provide scheduled service or not in the basic specialties inpatient unit.

The study was approved by the Ethics Research Committee of the institution responsible for the protocol number 456,332 and Presentation Certificate for Ethics Assessment: 18675113.2.1001.5537 observance of the ethical force.

\section{Results}

Out of the 100 health professionals interviewed, 34 (34\%) were nurses, 34 (34\%) CHA, 22 (22\%) nursing technicians and 10 (10\%) doctors. These professionals were distributed in 27 health units, of which 71 (71\%) belonged to USF, 27 (27\%) to UBS and two $(2 \%)$ to the mixed health unit.

Regarding the evaluation of supported self-care, it was identified the four items investigated a reasonable capacity of attention to people with TB. In the item referring to records related to the support of professionals in the unit to the carrier of TB care for their health, these were performed in a standardized way. Regarding the support, trained health professionals that are part of the team provided this action. However, medication adherence was not in- volved. Concerning the hosting of the concerns of people with TB and their families, this was done and solved in the health unit. Finally, related to behavior change interventions (stop smoking, drinking and drug use) of patients with TB, this action was carried out through referral to specialized centers, as shown in Table 1.

In Table 1, supported self-care in the municipality was rated as reasonable capacity, and 21 (78\%)

Table 1. Self-care supported by health unit type of service and professional function of the unit. Natal/RN/Brazil, 2016.

\begin{tabular}{|c|c|c|c|c|}
\hline Analysis category & Average & $\begin{array}{l}\text { Standard } \\
\text { deviation }\end{array}$ & $\mathrm{N}$ & Classification \\
\hline \multicolumn{5}{|l|}{ Item } \\
\hline $\begin{array}{l}\text { Records related } \\
\text { to the support of } \\
\text { professionals in } \\
\text { UBS for TB carrier } \\
\text { take care of their } \\
\text { health }\end{array}$ & 8.1 & 2.7 & 100 & Reasonable \\
\hline $\begin{array}{l}\text { Support for the } \\
\text { TB patients takes } \\
\text { care of their } \\
\text { health }\end{array}$ & 7.1 & 3.2 & 100 & Reasonable \\
\hline $\begin{array}{l}\text { Home of the } \\
\text { concerns of } \\
\text { people with TB } \\
\text { and their families }\end{array}$ & 6.9 & 2.1 & 100 & Reasonable \\
\hline $\begin{array}{l}\text { TB interventions } \\
\text { in patients with } \\
\text { behavior change }\end{array}$ & 6.7 & 29 & 100 & Reasonable \\
\hline City & 7.2 & 1.8 & 100 & Reasonable \\
\hline \multicolumn{5}{|l|}{ Health unit } \\
\hline UBS A & 7.9 & 0.5 & 02 & Reasonable \\
\hline UBS B & 7.4 & 06 & 04 & Reasonable \\
\hline UBS C & 7.1 & 0.2 & 02 & Reasonable \\
\hline UBS D & 8.5 & 1.3 & 03 & Reasonable \\
\hline UBS E & 7.6 & 0.2 & 02 & Reasonable \\
\hline UBS F & 6.2 & 1.0 & 05 & Reasonable \\
\hline UBS G & 3.6 & 0.5 & 02 & Basic \\
\hline UBS H & 6.3 & 0.7 & 02 & Reasonable \\
\hline Mixed unit A & 8.8 & 0.7 & 02 & Reasonable \\
\hline USF A & 7.1 & 2.3 & 04 & Reasonable \\
\hline USF B & 8.8 & 1.1 & 07 & Reasonable \\
\hline
\end{tabular}




\begin{tabular}{|c|c|c|c|c|}
\hline Analysis category & Average & $\begin{array}{l}\text { Standard } \\
\text { deviation }\end{array}$ & $\mathrm{N}$ & Classification \\
\hline \multicolumn{5}{|l|}{ Health unit } \\
\hline USF C & 8.3 & 2.3 & 09 & Reasonable \\
\hline USF D & 7.6 & 0.9 & 03 & Reasonable \\
\hline USF E & 8.4 & 1.4 & 03 & Reasonable \\
\hline USF F & 7.3 & 1.0 & 03 & Reasonable \\
\hline USF G & 8.4 & 0.6 & 03 & Reasonable \\
\hline USF H & 7.1 & 0.2 & 02 & Reasonable \\
\hline USF I & 6.1 & 2.0 & 10 & Reasonable \\
\hline USF J & 5.6 & 1.6 & 03 & Básica \\
\hline USF K & 6.7 & 0.7 & 04 & Reasonable \\
\hline USF L & 9.2 & 1.8 & 04 & Great \\
\hline USF M & 4.6 & 0.5 & 02 & Basic \\
\hline USF N & 4.6 & 1.5 & 03 & Básica \\
\hline USF O & 7.8 & 1.3 & 03 & Reasonable \\
\hline USF P & 9 & 0.6 & 04 & Great \\
\hline USF Q & 6 & 1.7 & 04 & Reasonable \\
\hline USF R & 6.9 & 1.6 & 05 & Reasonable \\
\hline \multicolumn{5}{|l|}{ Heath service type } \\
\hline UBS* & 6.8 & 1.5 & 27 & Reasonable \\
\hline USF* & 7.4 & 1.9 & 71 & Reasonable \\
\hline Mixed* & 8.8 & 0.7 & 02 & Reasonable \\
\hline \multicolumn{5}{|l|}{ Unit function } \\
\hline $\begin{array}{l}\text { Health } \\
\text { community } \\
\text { agent* }\end{array}$ & 7.5 & 1.9 & 34 & Reasonable \\
\hline Nurse* & 6.9 & 1.6 & 34 & Reasonable \\
\hline Doctor* & 7.6 & 2.2 & 10 & Reasonable \\
\hline $\begin{array}{l}\text { Nursing } \\
\text { technician* }\end{array}$ & 7.2 & 2.0 & 22 & Reasonable \\
\hline & $\begin{array}{l}* * \text { * Havin } \\
\text { : Not Havin }\end{array}$ & $\begin{array}{l}\text { Ig statistical } \\
\text { Ig statistical }\end{array}$ & $\begin{array}{l}\text { gnific } \\
\text { gnific }\end{array}$ & $\begin{array}{l}\text { ance for ANOVA; } \\
\text { ance for ANOVA. }\end{array}$ \\
\hline
\end{tabular}

of health units also showed that classification, in contrast, four units (15\%) were classified as basic capacity and two (7\%) with great capacity. Moreover, there were no statistical differences in the classification of types of units and health professionals when associated with items related to supported self-care, and all classified with a reasonable capacity for attention to TB carrier.

\section{Discussion}

TB worldwide is a public health problem, with required targets for its control. Brazil is among the 22 countries with $80 \%$ of the global burden of TB, and therefore a country prioritized by the World Health Organization to control the disease [6].

Given the significant of this disease occurrence, as well as the complexity involved in the process of diagnosis and treatment of TB, it becomes a shared performance of health professionals working in primary care, which should contain trained professionals to prescribe the basic treatment, monitoring of cases, with control by the end of treatment, and identify adverse effects from the treatment [12].

In this context, it is important to highlight numbers as the quality of human resources devoted to control and prevention of the managerially TB in health facilities. In other studies, it is possible to realize the identification of a weakness in relation to the quantity and quality of the professionals working in these units, plus a distorted view of those about the actions related to the control of this disease in services, a reality that resonates with problems in the diagnosis and as in the treatment of these individuals. Thus, this study finds that a lack of professionals in the units, with the consequent heavy workload, may compromise the resoluteness of the units, the link between patients and professionals and interfere in the accession process to the treatment [13].

In this study, it was found that the performance of the investigated professionals, nurse, medical, nursing technician and CHA was reasonable, and there was no statistical difference between these professionals when assessed supported self-care items in aid of people with TB and their families, in contrast to the above-identified in the literature.

Development of actions in the control of this disease is often linked to the performance of the professional category that performs. Thus, it is very important that each of them knows the actions to take effect in their work process. In a study on the 
actions of professionals directly involved in the care of TB in primary care, in which there were doctors, nurses, nursing technicians and CHA interviewed, we identified that among the actions developed during user assistance with TB, such as monitoring treatment and active search for missing, nurses and CHA were professionals with more significant action. However, the educational activities had a deficit in all categories, as less than half of the respondents held this intervention [14].

Among the actions performed by these professionals, there is supported self-care effective to help people with TB and their families cope with the challenges of living and treat the disease and reduce complications and associated symptoms. Therefore, among the items of supported self-care, the support provided by these professionals is highlighted, such as health education and the establishment of a connection to the TB patients to take charge of their health. However, in this study, as reported in the above research, the support related to the health education, somewhat deficient lies, keeping in mind that despite being offered by professionals trained team members, that does not involve adherence drug.

On health education, research states the existing deficit in the Family Health Strategy in the educational activities by professionals in line with the recommendations by the Ministry of Health, being evident in this study, emphasizing supplied to the clinical nature activities. This reality can interfere with the care provided to TB carrier [15].

In this context, another state ratifies the expressed above, stating the little focus given educational activities by health facilities teams. When carried out, they direct the learning of patients for content delivery perspective, with little emphasis on the user's autonomy and reflective practices. This reality has been identified, according to the study, due to the shortage of qualified professionals [16].

Related to medication adherence important action in support of the supported self-care study on adhe- rence to TB treatment compared two groups, those with supervised and self-administered treatment, and noted that compliance was $6.1 \%$ higher in patients with supervised treatment, and $91.6 \%$ of patients completed the standard treatment compared to the other group only $85.5 \%$ achieved complete scheme [17].

Other research on the determinants responsible for the abandonment of treatment for people with TB says that among the reasons, there are the difficulties of access to treatment and lack of bond between the professional and the patient [7]. In this respect, the establishment of bonds between the professional and the patient is identified as one of the relevant factors for adherence. When this interaction is weakened between professional-patientservice, feelings of abandonment, neglect and uncertainty are identified in the patient [18].

The literature reveals that among the elements working against the establishment of bonds between professionals and patients, there is the rotation of professionals working in primary care, which often operate in the cities because of partisan political statements, being asked to leave their jobs when the mandate of a particular political ends [13].

For the item host, the concerns of people with TB and their families, it was also classified as reasonable and performed at the unit. Authors punctuate the monitoring process of TB patients by professionals Primary Care should be guided by the precepts established by the humanization of care. Thus, active listening of the user, identifying the current needs of identified health will better link between patient and professional, as the carrier becomes more open to staff on therapeutic approaches, avoiding the dropout rates of treatment and the occurrence of resistance to antibiotics [15].

In a study on host three areas are identified: the first as being responsible for the health care organization; the second as an attitude towards the individual to be met, and the third as a management of the Unified Health System device, in which are 
associated with comprehensiveness and universality. Moreover, from the host, some user assistance of peculiarities can be achieved, such as increasing the bond between patient and professional, with consequent stimulus to self-care, as well as universal access, best-qualified assistance and a more humane practice [19].

Concerning interventions applied to TB carrier to changing behavior, it was found that these are carried out using referrals to specialized centers. However, the ideal would be that these interventions were part of the unit's routine through motivational interviewing or groups. Motivation is a state internally identified in each, which is the desire for change. In this sense, for the success of the individual change process is crucial that health professionals perceive that level has located this desire so that it can act in this traffic or even establish criteria to effect the changes already in place [9].

In this respect, motivational interviewing may be invested as a resource for supported self-care to individuals with $T B$, with the objective to promote/encourage individual behavior change from the need of the individual. Thus, it is founded, collaborative criteria, evocative and respect for the autonomy of the person. Among the principles of motivational interviewing coexist: express empathy, develop discrepancy, avoid arguments, keep the resistance and support self-efficacy [9].

Regarding the records related to the support of professionals in the unit to the carrier of TB for their health care, these are conducted in a standardized way, however, not always articulated with TB carrier care plan.

In this issue, a study on the quality of analysis of records of TB in primary health care, it was the high absence of records relating to education, occupation and comorbidity of patients seen with the disease. Moreover, this lack of records committed to identifying risk factors responsible for non-adherence, problem viewed as frequent in the unit, making up $24.7 \%$ of the trainees. In this context, we emphasize the importance of keeping up to date and well filled out the records TB carrier, aimed at better monitoring of the evolution of the treatment and the disease, and the proper completion of the records of patients responsibility of all staff involved [20].

When assessing health facilities, most ranks as reasonable in the range of supported self-care. However, it is noteworthy that four of them were classified as basic capacity and two with great capacity. This distinction between the units and their capabilities should not be present, due to the standardization advocated in the care of TB carrier user, and should, therefore, have the same prerogatives, requiring further investigation about these discrepancies. This study did not focus this fact. However, it glimpses a suggestion, identification in future studies regarding this issue.

Research states that issues such as quantitative and qualitative weaknesses of human resources units and distorted views of TB control actions, such as centralization and fragmentation of these actions can be one of the reasons that influence the performance of the teams of each unit [13]. In this perspective, among the reasons for the occurrence of the above problem pointed this present study may be related to organizational problems of each unit, absolving the blame the higher professionals.

Finally, when compared to items of supported self-care related to the types of units investigated in this study, the overall rating of the Mixed Units, UBS and USF were considered with a reasonable capacity. Although this study has not been identified distinctions between units, research shows a greater involvement of health professionals in TB control among the UFS compared to UBS [13].

\section{Conclusion}

It is concluded that the supported self-care is verified with a reasonable capacity concerning records, support, care and behavior change interventions in 
the care of patients with $T B$, when measured between the types of units (UBS, USF, and Mixed) and between health professionals (nursing technicians, nurses, doctors and (HA), not being identified distinctions between them. However, when measured by units, four had a basic capacity, and two had a great capacity, a reality that may be linked to the organizational structure of each unit by working professionals.

From this study, it was found that the supported self-care practiced by professionals of primary care services from a municipality in Northeast Brazil operates effectively, to assist individuals with TB to live with the disease and treatment. However, they need to advance the care attention to this clientele reaching the optimal classification, so that they can meet all specific needs for effective self-care globally.

It is expected that this study contributes to reflections and actions taken by health professionals with the encouragement and participation for self-care supported to people with TB.

The limitations of the study are the difference of quantitative professionals by professional category which prevents draw conclusions to the population categories.

\section{References}

1. Clementino FS, Miranda FAN. Acessibilidade: identificando barreiras na descentralização do controle da tuberculose nas unidades de saúde da família. Rev enferm UERJ. 2010; 18(4): 584-90.

2. Cheever KH, Hinkle JL. Brunner \& Suddarth: Manual de Enfermagem Médico-Cirúrgica. 13a ed. Rio de Janeiro: Guanabara Koogan; 2015.

3. World Health Organization (WHO). Tuberculosis: global facts. 2012 [cited 2016 Mar 11]. Available from: www.who.int/tb.

4. DATASUS. Casos novos de tuberculose por região. 2014 [cited 2016 Mar 11]. Available from: http://tabnet.datasus.gov.br/cgi/ tabcgi.exe?pacto/2014/cnv/coapcirbr.def.

5. World Health Organization (WHO). Global tuberculosis report 2015. 20a ed. 2015.
6. Brasil (Ministério da Saúde). Secretaria de Vigilância em Saúde. Departamento de Vigilância Epidemiológica. Manual de recomendações para o controle da tuberculose no Brasil. Brasília: Ministério da Saúde; 2011 [cited 2016 Mar 11]. Available from: http://www.cve.saude.sp.gov.br/htm/TB/mat tec/manuais/ MS11 Manual Recom.pdf.

7. Couto DV, Carvalho RN, Azevedo EB, Morais MN, Pinheiro PGOD, Faustino EB. Fatores determinantes para o abandono do tratamento da tuberculose: representações dos usuários de um hospital público. Saúde Debate. 2014;38(102): 572-81.

8. Galvão MTRLS, Janeiro JMSV. O autocuidado em enfermagem: autogestão, automonitorização e gestão sintomática como conceitos relacionados. Rev min enferm. 2013; 17(1): 225-30.

9. Cavalcanti AM, Oliveira ACL. Secretaria Municipal de Saúde. Autocuidado apoiado: manual do profissional de saúde. Curitiba; 2012 [cited 2016 Mar 13]. Available from: http://apsredes.org/ site2012/wp-content/uploads/2012/11/manual_auto-cuidado curitiba.pdf

10. Moysés ST, Filho ADS, Moysés SJ. Validação transcultural dos instrumentos ACIC e PACIC para avaliação da percepção das equipes e das pessoas usuárias sobre a atenção as condições crônicas. Laboratório de inovações no cuidado das condições crônicas na APS: a implantação do Modelo de Atenção as Condições Crônicas na UBS Alvorada em Curitiba, Paraná. Brasilia: Organização Pan-Americana da Saúde/Conselho Nacional de Secretarias de Saúde; 2012.

11. Brasil. Ministério da saúde. Conselho Nacional de Saúde. Diretrizes e normas regulamentadoras da pesquisa envolvendo seres humanos: Resolução n 466/2012. Diário Oficial da República Federativa do Brasil; 2012 [cited 2016 Mar 16]. Available from: http://conselho.saude.gov.br/resolucoes/2012/ Reso466.pdf

12. Unis G. Papel da atenção básica no controle da tuberculose. Revista de Epidemiologia e Controle de Infecção. 2012; 2(3): 1-2.

13. Monroe AA, Gonzales RIC, Palha PF, Sassaki CM, Ruffino Netto A, Vendramini SHF et al. Envolvimento de equipes da atenção básica à saúde no controle da tuberculose. Rev Esc Enferm USP. 2008; 42(2):262-7.

14. Santos TMMG, Nogueira LT, Arcêncio RA. Atuação de profissionais da Estratégia Saúde da Família no Controle da Tuberculose. Acta Paul Enferm. 2012; 25(6):954-61.

15. Clementino FS, Miranda FAN. Tuberculose: acolhimento e informação na perspectiva da visita domiciliária. Rev enferm UERJ. 2015; 23(3):350-4. 
16. Sá LD, Gomes ALC, Carmo JB, Souza CMJ, Palha PF, Alves RS et al. Educação em saúde no controle da tuberculose: perspectiva de profissionais da estratégia Saúde da Família. Rev Eletr Enf. 2013; 15(1):103-11.

17. Vieira $A A$, Ribeiro $S A$. Adesão ao tratamento da tuberculose após a instituição da estratégia de tratamento supervisionado no município de Carapicuíba, Grande São Paulo. J Bras Pneumol. 2011; 37(2):223-231.

18. Garcia MCC, Cirino ID, Elias TMN, Lira ALBC, Enders BC. Interação enfermeiro-paciente na adesão ao tratamento da tuberculose: reflexão à luz de Imogene King. Rev enferm UFPE on line. 2014; 8(supl. 1):2513-21.

19. Garuzi M, Achitti MCO, Sato CA, Rocha SA, Spagnuolo RS. Acolhimento na Estratégia Saúde da Família: revisão integrativa. Rev Panam Salud Publica. 2014;35(2):144-9.

20. Theme Filha MM, Daumas RP, Alves LC, Leimann BCQ, Engstrom EM. Análise da tuberculose em uma unidade de Atenção Primária à Saúde na cidade do Rio de Janeiro: perfil clínico, resultado de tratamento e qualidade dos registros. Cad Saúde Colet. 2012; 20 (2):169-76.

Publish in International Archives of Medicine

International Archives of Medicine is an open access journal publishing articles encompassing all aspects of medical science and clinical practice. IAM is considered a megajournal with independent sections on all areas of medicine. IAM is a really international journal with authors and board members from all around the world. The journal is widely indexed and classified Q1 in category Medicine. 